\title{
Validitas Video Pembelajaran Topik Jarak dan Kecepatan pada Pembelajaran Matematika SD
}

\author{
Ni Komang Sri Asih Arina1*, I Made Citra Wibawa ${ }^{2}$, Desak Putu Parmiti ${ }^{3}$
}

1,2,3 Program Studi Pendidikan Guru Sekolah Dasar, Universitas Pendidikan Ganesha, Singaraja, Indonesia

\section{A R T I C L E I N F O}

Article history:

Received May 09, 2021

Revised May 15, 2021

Accepted June 28, 2021

Available online July 25, 2021

Kata Kunci:

Video, Jarak, Kecepatan, 4D

Keywords:

Video, Distance, Speed, $4 D$

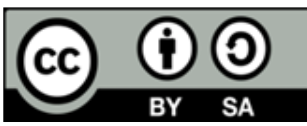

This is an open access article under the CC BY-SA license.

Copyright $(2021$ by Author. Published by Universitas Pendidikan Ganesh

\begin{abstract}
A B S T R A K
Penerapan pembelajaran daring akibat pandemi Covid-19 yang secara tiba-tiba, menyebabkan guru mengalami kesulitan dalam menentukan media pembelajaran yang sesuai untuk digunakan. Oleh karena itu, dirasa perlu untuk mengembangkan media pembelajaran yang bisa mengatasi masalah tersebut, salah satunya adalah video pembelajaran. Penelitian ini bertujuan untuk menghasilkan media video pembelajaran pada topik jarak dan kecepatan kelas V SD yang teruji validitasnya. Model pengembangan yang digunakan pada penelitian ini adalah model 4D. Subjek pada penelitian ini adalah 1 orang ahli media, 1 orang ahli materi, 1 orang praktisi, dan 6 orang siswa, sedangkan objek penelitian ini adalah validitas media video. Metode pengumpulan data pada penelitian ini adalah metode kuesioner/angket dan wawancara. Data yang dihasilkan dalam penelitian ini bersifat kualitatif dan kuantitatif. Data yang diperoleh kemudian dianalisis dengan menggunakan rumus mean untuk mengetahui rata-rata validasi media video pembelajaran. Berdasarkan analisis data, diketahui bahwa pengembangan produk video pembelajaran memiliki rata-rata berada pada rentangan $4,01<X \leq 5,01$, dengan kualifikasi "sangat baik". Jadi, dapat disimpulkan bahwa produk video pembelajaran topik jarak dan kecepatan pada mata pelajaran matematika siswa kelas V SD dinyatakan valid.
\end{abstract}

\section{A B S T R A C T}

The application of online learning due to the sudden Covid-19 pandemic has caused teachers to have difficulty in determining the appropriate learning media to use. Therefore, it is necessary to develop learning media that can overcome these problems, one of which is learning videos. This study aims to produce learning video media on the topic of distance and speed for fifth grade elementary school students whose validity has been tested. The development model used in this research is the $4 D$ model. The subjects in this study were 1 media expert, 1 material expert, 1 practitioner, and 6 students, while the object of this study was the validity of video media. The method of data collection in this study is the method of questionnaires/questionnaires and interviews. The data generated in this study are qualitative and quantitative. The data obtained were then analyzed using the mean formula to determine the average validation of the learning video media. Based on data analysis, it is known that the development of instructional video products has an average range of $4.01<X 5.01$, with "very good" qualifications. So, it can be concluded that the video product of distance and speed learning topics in mathematics subjects for fifth grade elementary school students is declared valid.

\section{PENDAHULUAN}

Merebaknya virus covid-19 di wuhan china, sangat mempengaruhi berbagai sektor di dunia, salah satu sektor yang ikut terkena imbas dari munculnya covid-19 adalah sektor pendidikan di dunia. Indonesia menjadi salah satu negara yang terdampak covid-19. Untuk mencegah semakin merebaknya penyebaran covid-19, pemerintah membuat beberapa kebijakan-kebijakan. Sistem pelaksanaan pendidikan mulai berubah, yang awalnya pendidikan dilakukan secara tatap muka berubah menjadi sistem pendidikan daring (dalam jaringan). Pembelajaran daring menjadi salah satu alternatif agar proses pembelajaran tetap bisa berlangsung (Hwang et al., 2020; Oktafia \& Wulandari, 2020). Hal ini dilakukan untuk mengurangi interaksi fisik sebagai upaya pencegahan penularan virus corona jenis baru atau covid-19 (Hong et al., 2021; D. L. Mishra et al., 2020; Oktawirawan, 2020). Pembelajaran daring menjadi salah satu inovasi proses pembelajaran yang mempergunakan teknologi informasi (Fitriyani et al., 2020). Pembelajaran muatan matematika di SD menjadi 
salah satu bagian dalam penerapan pembelajaran daring. Matematika dibelajarkan sebagai upaya dalam mempersiapkan generasi yang siap menghadapi tantangan di masa depan. Melalui pembelajaran matematika, siswa berlatih untuk mengembangkan kemapuan berpikir secara logis, kritis, kreatif, dan cermat dalam membuat sebuah keputusan serta simpulan (Prihanto \& Yunianta, 2018). Lebih lanjut, matematika hendaknya dibelajarkan melalui proses pembelajaran yang bermakna artinya materi yang dibelajarkan bisa dihubungkan dengan suatu fenomena yang terjadi pada kehidupan nyata begitu pula sebaliknya, sehingga siswa akan dapat belajar dengan lebih baik (Chauhan, 2017; Kenedi et al., 2018). Hal lainnya yang menjadi faktor penting dalam menunjang keberhasilan proses pembelajaran matematika adalah motivasi siswa dalam belajar. Membangun motivasi siswa dapat dilakukan dengan penggunaan model-model pembelajaran maupun menggunakan mediamedia pembelajaran yang inovatif (Aziz, 2018; Rachmawati et al., 2021). Kreativitas guru diperlukan untuk pengembangan dan pelaksanaan pembelajaran yang inovatif (Hidayah \& Sugiarto, 2015).

Namun kenyataanya dilapangan proses pembelajaran khususnya muatan matematika di SD masih jauh dari harapan. Penggunaan media ditengah situasi pembelajaran daring bisa dikatakat sangat kurang. Hal ini didukung dari hasil observasi yang telah dilakukan selama PLPbD di SD Negeri 2 Sepang Kelod, ada beberapa temuan yaitu proses pembelajaran hanya berpedoman pada buku siswa tanpa dibarengi penggunaan media. Hal ini mengakibatkan materi yang bersifat abstrak sulit untuk dipahami, salah satunya adalah materi jarak dan kecepatan. Selain itu, tanpa adanya media dalam pembelajaran menimbulkan perasaan mudah jenuh yang sering kali diarasakan siswa. Masalah ini juga diungkapkan pada beberapa penelitian yang ada sebelumnya. Akibat dari keterbatasan ketersedian media pembelajaran membuat guru lebih memilih untuk menggunakan metode ceramah dalam proses pembelajaran dan pada akhirnya menimbulkan suasana pembelajaran yang kurang menarik dan kurang bermakna (Atmoko et al., 2017; Unaenah \& Sumantri, 2019; Widodo \& Kartikasari, 2017) Lebih lanjut, pemberlakuan pembelajaran daring yang secara tiba-tiba menjadi tantangan tersendiri untuk guru dan siswa (Mishra et al., 2020; Scherer et al., 2021). Jika, masalah ini tetap dibiarkan tanpa ada upaya untuk segera menanggulanginya, maka tidak menutup kemungkinan kedepan masalah ini akan menjadi masalah yang serius tidak hanya pada saat pembelajaran daring tetapi juga pada pembelajaran tatap muka secara langsung.

Sebagai upaya untuk menangani masalah di atas, maka diperlukan sebuah inovasi khususnya dalam pengembangan sebuah media pembelajaran. Salah satu media pembelajaran yang sesuai untuk dikembangkan adalah media video pada materi jarak dan kecepatan. Media video dipilih karena dirasa mampu untuk mendukung proses pembelajaran daring. Adanya media video pembelajaran dapat membuat materi yang disajikan lebih menarik dan sistematis, sehingga siswa dapat belajar dengan atau tanpa bantuan seorang guru. Selain itu, media ini dipilih karena proses pembelajaran saat ini perlu beradaptasi dengan kemajuan teknologi yang begitu pesat. Peran teknologi telah berkembang dari sekadar alat studi dan penyelidikan ke pendekatan dan penggunaan terpadu dalam pendidikan (Tuma, 2021). Media seperti dokumen, gambar, video, audio menjadi modal utama dalam mengembangkan pembelajaran daring (Rigianti, 2020). Siswa merasa sangat bersemangat mengikuti pembelajaran daring ketika guru menyajiakannya melalui video (Anugrahana, 2020). Hasil penelitian menunjukan perpaduan model pembelajaran dengan media video memberikan dapak positif terhadap peningkatan respons dan hasil belajar matematika siswa SD (Hariati et al., 2020; Janah et al., 2019; Masrifatun, 2020; Perdana \& Slameto, 2016). Namun, video yang digunakan dalam penelitian-penelitian tersebut belum ada yang mengambil materi jarak dan kecepatan pada muatan matematika kelas V SD. Selain itu, media yang dikembangkan ini memiliki beberpa kelebihan, yaitu: penggunaan contoh yang digunakan dalam memaparkan konsep menggunakan kejadian-kejadian yang ada disekitar lingkungan siswa, sehingga menjadi lebih bermakana; dan menggunakan background, tulisan, animasi yang menarik. Tujuan pengembangan media video pembelajaran ini adalah untuk menghasilkan media yang teruji validitasnya. Harapan dikembangkannya media video ini adalah siswa lebih tertarik untuk mempelajari pokok bahasan matematika terutama pada topik jarak dan kecepatan, yang tentunya berkaitan dengan kehidupan sehari-hari, sehingga pembelajaran yang didapat akan lebih bermakna dan dapat meningkatkan hasil belajar matematika siswa.

\section{METODE}

Penelitian ini merupakan penelitian pengembangan media video pembelajaran pada topik jarak dan kecepatan. Model yang digunakan dalam penelitian ini yaitu model 4D (Define, Design, Development, Desseminate). Tahap define adalah tahap untuk menetapkan dan mendefinisikan syarat-syarat pembelajaran. Tahap define ini mencakup lima langkah pokok, yaitu analisis ujung depan (front-end analysis), analisis siswa (learner analysis), analisis tugas (task analysis), analisis konsep (concept analysis) dan perumusan tujuan pembelajaran (specifying instructional objectives). Analisis ujung depan bertujuan untuk memunculkan dan menetapkan masalah dasar yang dihadapi dalam pembelajaran, sehingga diperlukan suatu pengembangan bahan ajar. Selanjutnya analisis siswa merupakan telaah tentang karakteristik siswa yang sesuai dengan desain pengembangan perangkat pembelajaran. Karakteristik itu meliputi latar belakang kemampuan akademik (pengetahuan), perkembangan kognitif, serta keterampilan-keterampilan individu atau sosial yang berkaitan dengan topik pembelajaran, media, format dan bahasa yang dipilih. Analisis konsep dilakukan untuk 
mengidentifikasi konsep pokok yang akan diajarkan, menyusunnya dalam bentuk hirarki, dan merinci konsepkonsep individu ke dalam hal yang kritis dan yang tidak relevan. Analisis membantu mengidentifikasi kemungkinan contoh dan bukan contoh untuk digambarkan dalam mengantar proses pengembangan. Analisis tugas bertujuan untuk mengidentifikasi keterampilan-keterampilan utama yang akan dikaji oleh peneliti dan menganalisisnya kedalam himpunan keterampilan tambahan yang mungkin diperlukan. Sedangkan perumusan tujuan pembelajaran berguna untuk merangkum hasil dari analisis konsep dan analisis tugas untuk menentukan perilaku objek penelitian.

Tahap perancangan bertujuan untuk merancang perangkat pembelajaran. Empat langkah yang harus dilakukan pada tahap ini, yaitu: pertama penyusunan standar tes (criterion-test construction), kedua, pemilihan media (media selection) yang sesuai dengan karakteristik materi dan tujuan pembelajaran, ketiga pemilihan format (format selection), yakni mengkaji format-format bahan ajar yang ada dan menetapkan format bahan ajar yang akan dikembangkan, keempat yaitu membuat rancangan awal (initial design) sesuai format yang dipilih. Tahap pengembangan adalah tahap untuk menghasilkan produk pengembangan yang dilakukan melalui dua langkah, yakni: penilaian ahli (expert appraisal) yang diikuti dengan revisi, dan uji coba pengembangan (developmental testing). Uji coba lapangan dilakukan untuk memperoleh masukan langsung berupa respon, reaksi, komentar siswa, dan para pengamat terhadap perangkat pembelajaran yang telah disusun. Proses diseminasi merupakan suatu tahap akhir pengembangan. Tahap diseminasi dilakukan untuk mempromosikan produk pengembangan agar bisa diterima pengguna, baik individu, suatu kelompok, atau sistem. Produsen dan distributor harus selektif dan bekerja sama untuk mengemas materi dalam bentuk yang tepat.

Subjek pada penelitian pengembangan ini adalah para ahli yang berkompeten dibidangnya, dimana para ahli tersebut terdiri dari 1 orang ahli materi, 1 orang ahli media, 1 orang guru, dan 6 orang siswa. Data yang diperoleh pada penelitian ini dikelompokkan menjadi dua, yaitu data kualitatif dan data kuantitatif. Data kualitatif adalah data yang disajikan dalam bentuk kata-kata berupa tanggapan, dan saran yang diperoleh dari tahap review oleh ahli media dan pembelajaran matematika. Data kuantitatif adalah data berupa skor yang diperoleh dari lembar validitas media video pembelajaran yang diisi oleh para ahli. Sedangkan Metode pengumpulan data yang digunakan dalam penelitian pengembangan ini adalah metode kuesioner dan Instrumen yang digunakan dalam penelitian pengembangan ini adalah rating scale (Ilhami \& R, 2017). Instrumen yang telah disusun selanjutnya dilakukan tahap uji validitas. Uji validitas dilakukan untuk mengetahui tingkat kevalidan instrumen tersebut dengan menggunakan rumus Gregory. Setelah rata-ratanya diperoleh selanjutnya dikonversikan dengan tabel konversi tingkat pencapaian skala 5. Kisi-kisi instrument ditunjukkan pada tabel 1, 2,3 , dan 4 .

Tabel 1. Kisi-kisi Validasi Ahli Media

\begin{tabular}{|c|c|c|c|}
\hline No. & Aspek & Indikator & No. Butir \\
\hline \multirow[t]{6}{*}{1} & Visual & a. Kejelasan gambar & 1 \\
\hline & & b. Kesesuaian pengambilan gambar & 2 \\
\hline & & c. Kemenarikan warna, background, gambar, dan animasi & 3 \\
\hline & & d. Kecepatan gerak gambar & 4 \\
\hline & & e. Ketepatan pencahayaan & 5 \\
\hline & & f. Kesesuaian judul dengan video & 6 \\
\hline \multirow[t]{3}{*}{2} & Audio & a. Kejelasan suara & 7 \\
\hline & & b. Ritme suara & 8 \\
\hline & & c. Kesesuaian music & 9 \\
\hline \multirow[t]{2}{*}{3} & Tipografi & a. Pemilihan jenis teks & 10 \\
\hline & & b. Ketepatan ukuran teks & 11 \\
\hline \multirow[t]{7}{*}{4} & Penyajian & a. Memiliki daya Tarik & 12 \\
\hline & & b. Durasi waktu & 13 \\
\hline & & c. Kejelasan alur cerita & 14 \\
\hline & & d. Kesesuaian video dengan karateristik siswa & 15 \\
\hline & & a. Kejelasan sasaran & 16 \\
\hline & & b. Kejelasan pembahasan & 17 \\
\hline & & Jumlah & 17 \\
\hline
\end{tabular}

Tabel 2. Kisi-kisi Instrumen Ahli Materi

\begin{tabular}{ccccc}
\hline No. & Aspek & & Indikator & No. Butir \\
\hline 1 & Materi & a. & Kejelasan materi pembelajaran & 1 \\
& & b. & Kesesuaian video pembelajaran dengan tujuan pembelajaran & 2 \\
& & c. & Kesesuaian video pembelajaran dengan materi pembelajaran & 3 \\
& d. & Ketepatan pembagian dan keruntutan materi & 4 \\
\hline
\end{tabular}




\begin{tabular}{|c|c|c|c|}
\hline No. & Aspek & Indikator & No. Butir \\
\hline \multirow{7}{*}{2} & \multirow{7}{*}{ Kebahasaan } & e. Memudahkan pemahaman siswa terhadap materi & 5 \\
\hline & & f. Meningkatkan perhatian siswa pada pembelajaran & 6 \\
\hline & & g. Video memotivasi minat belajar siswa & 7 \\
\hline & & a. Kesesuaian bahasa dengan kaidah bahasa Indonesia & 8 \\
\hline & & b. Kalimat yang digunakan mudah dipahami dan dimengerti & 9 \\
\hline & & c. Sifat komunikatif bahasa yang digunakan & 10 \\
\hline & & d. Tingkat bahasa dengan kognitif siswa & 11 \\
\hline \multirow[t]{2}{*}{2} & Kompetensi & a. Tujuan pembelajaran sesuai dengan format ABCD & 12 \\
\hline & & Kesuaian tujuan pembelajaran dengan indikator pembelajaran & 13 \\
\hline \multirow[t]{3}{*}{3} & Metode & a. Kesesuaian persepsi/ilustrasi dengan materi & 14 \\
\hline & & b. Kejelasan contoh kasus/peristiwa yang disertakan & 15 \\
\hline & & c. Ketepatan cara penyajian materi & 16 \\
\hline \multirow[t]{2}{*}{5} & Penilaian & Kesesuaian soal yang disajikan sesuai dengan materi yang disajikan & 17 \\
\hline & & Jumlah & 17 \\
\hline
\end{tabular}

Tabel 3. Kisi-kisi Instrumen Video untuk Praktisi

\begin{tabular}{|c|c|c|c|}
\hline No & Aspek & Indikator & No. Butir \\
\hline \multirow[t]{6}{*}{1} & Visual & a. Kejelasan gambar & 1 \\
\hline & & b. Kesesuaian pengambilan gambar & 2 \\
\hline & & c. Kemenarikan warna, background, gambar, dan animasi & 3 \\
\hline & & d. Kecepatan gerak gambar & 4 \\
\hline & & e. Ketepatan pencahayaan & 5 \\
\hline & Audio & a. Kejelasan suara & 6 \\
\hline \multirow[t]{2}{*}{2} & & b. Ritme suara & 7 \\
\hline & & c. Kesesuaian music & 8 \\
\hline \multirow[t]{2}{*}{3} & Tipografi & a. Pemilihan jenis teks & 9 \\
\hline & & b. Ketepatan ukuran teks & 10 \\
\hline \multirow[t]{4}{*}{4} & Materi & d. Kejelasan materi pembelajaran & 11 \\
\hline & & e. Kesesuaian video pembelajaran dengan tujuan pembelajaran & 12 \\
\hline & & f. Kesesuaian video pembelajaran dengan materi pembelajaran & 13 \\
\hline & & g. Ketepatan pembagian dan keruntutan materi & 14 \\
\hline \multirow[t]{4}{*}{5} & Kebahasaan & a. Kesesuaian bahasa dengan kaidah bahasa Indonesia & 15 \\
\hline & & b. Kalimat yang digunakan mudah dipahami dan dimengerti & 16 \\
\hline & & c. Sifat komunikatif bahasa yang digunakan & 17 \\
\hline & & d. Tingkat bahasa dengan kognitif siswa & 18 \\
\hline \multirow[t]{5}{*}{6} & Keterpaduan & a. Memiliki daya Tarik & 19 \\
\hline & & b. Keterpaduan aspek visual & 20 \\
\hline & & c. Kesesuaian gambar dan ilustrasi & 21 \\
\hline & & d. Durasi waktu & 22 \\
\hline & & e. Kejelasan alur cerita & 23 \\
\hline
\end{tabular}

Tabel 4. Kisi-kisi Instrumen Uji Coba Perorangan dan Kelompok Kecil

\begin{tabular}{|c|c|c|c|}
\hline No & Komponen & Indikator & No Butir \\
\hline \multirow[t]{4}{*}{1} & Menarik minat & 1. Kemenarikan kemasan (cover) CD. & 1 \\
\hline & siswa & 2. Kemenarikan tampilan video pembelajaran. & 2 \\
\hline & & 3. Kemenarikan gambar yang ditampilkan. & 3 \\
\hline & & 4. Kejelasan dan kemenarikan warna yang disajikan. & 4 \\
\hline \multirow[t]{3}{*}{2} & Penyajian materi & 1. Materi yang disajikan jelas. & 5 \\
\hline & & 2. Materi yang disajikan mudah dipahami. & 6 \\
\hline & & 3. Contoh yang diberikan dalam materi mudah dipahami. & 7 \\
\hline 3 & $\begin{array}{l}\text { Meningkatkan } \\
\text { perhatian siswa }\end{array}$ & Video pembelajaran mampu meningkatkan perhatian. & 8 \\
\hline 4 & Memotivasi & Video pembelajaran mampu memotivasi belajar. & 9 \\
\hline \multirow[t]{3}{*}{5} & Kejelasan suara & 1. Kejelasan suara narrator & 10 \\
\hline & & 2. Kesesuaian musik. & 11 \\
\hline & & Jumlah & 11 \\
\hline
\end{tabular}




\section{HASIL DAN PEMBAHASAN}

Hasil

Model pengembangan yang digunakan pada penelitian ini adalah model 4D. Model 4D terdiri dari empat tahapan, yaitu: Pendefinisian (Define), Perancangan (Design), Pengembangan (Development), Penyebaran (Desseminate), akan tetapi karena keterbatasan waktu, biaya, tenaga, dan sumber daya, tahap penyebaran tidak dilaksanakan pada penelitian ini. Pada penelitian ini hanya sampai tahap Pengembangan (Development). Hasil penelitian ini berupa media video pembelajaran kelas $V$ yang dinyatakan valid. Tingkat validitas media diperoleh melalui analisis hasil penilaian yang dilakukan oleh para ahli.

\section{Tahap Pendefinisian (Define).}

Tahap define ini mencakup lima langkah pokok, yaitu analisis ujung depan (front-end analysis), analisis siswa (learner analysis), analisis tugas (task analysis), analisis konsep (concept analysis) dan analisis tujuan pembelajaran (specifying instructional objectives). Pertama, dilakukan analisis ujung depan (front-end analysis). Pada tahap ini dilakukan observasi untuk mengetahui kebutuhan dan permasalahan yang ada disekolah terkait dengan pembelajaran. Observasi dilakukan dengan cara melakukan wawancara kepada guru serta melakukan pengamatan berkaitan dengan cara guru memberikan materi pembelajaran. Dengan begitu akan ditemukan masalah yang dihadapi oleh guru terkait pembelajaran serta kaitannya dengan karakateristik siswa serta ketersediaan sarana dan fasilitas pendukung di sekolah dapat terpecahkan. Berdasarkan hasil wawancara dengan guru kelas $\mathrm{V}$ di SD, didapat beberapa permasalahan dalam proses pembelajaran saat ini, khususnya dalam pembelajaran matematika. Permalasalahan tersebut antara lain siswa yang sulit memahami materi pelajaran, media pembelajaran untuk pembelajaran daring yang kurang serta kurang mampunya pembuatan media yang sesuai dengan karakter siswa. Kedua dilakukan analisis siswa (learner analysis) untuk mengetahui dan menganalisis kebutuhan peserta didik, dilakukn dengan cara observasi dan wawancara dengen guru yang mengajar di kelas $\mathrm{V}$ untuk mengetahu karakteristik siswa, kebutuahan siswa, gaya belajar dalam memahamai materi pelajaran.Berdasaran hasil wawancara dengan guru kelas $\mathrm{V}$ diketahui bahwa ketika belajar daring, siswa tidak bersemangat dalam belajar dikarenakan proses pembelajaran yang guru berikan hanya dengan memberikan tugas dan meminta agar siswa mengerjakannya dengan bantuan buku pegangan yang dimiliki siswa. Hal tesebut dikarenakan terbatasnya alat bantu dalam proses pembelajaran daring. Ketiga dilakukan analisis tugas (task analysis). Analisis tugas dilakukan untuk mengetahui capaian kompetensi yang harus dicapai oleh siswa setelah melaksanakan pembelajaran. Adapun hasil analisis dalam penelitian pengembangan video pembelajaran sebagai berikut. Pada Kompetensi Dasar (KD), Menjelaskan perbandingan dua besaran yang berbeda (kecepatan sebaai perbandingan jarak dengan waktu, debiit sebagai perbandingan volume dan waktu. Selanjutnya pada Indikator Pencapaian Kompetensi, Menentukan hubungan kecepatan jarak dan waktu yang benar Mengitung kecepatan, jarak dan waktu. Analisis konsep dilakukan dengan mengidentifikasi materi pembelajaran matematika yang akan digunakan dalam pengembangan media video pembelajaran, dan analisis tujuan pembelajaran (specifying instructional objectives) dilakukan dengan merumuskan indikator pebelajaran, pencapaian kompetensi, dan hasil belajar matematika siswa kelas V SD.

\section{Perancangan (Design)}

Tahapan ini merupakan tahap untuk mendesain produk video pembelajaran. Setelah melakukan observasi kompetensi, maka dapat diidentifikasi kompetensi dasar dan indikator pada mata pelajaran matematika kelas V yang disajikan pada tabel 5. Setelah mengetahui KD dan Indikator langkah selanjutnya dilakukan dengan membuat storyboard. Langkah yang harus dilakukan di dalam mengembangkan video pembelajaran adalah mendesain atau mengkonsep isi dari video pembelajaran tersebut dengan membuat storyboard. Tujuan membuat storyboard ini adalah untuk mempermudah memahami alur materi yang akan dijelaskan dalam video pembelajaran yang akan dikembangkan. Selanjutnya dilakukan penyusunan RPP (Rencana Pelaksanaan Pembelajaran) yang bertujuan untuk mengarahkan kegiatan pembelajaran pada peserta didik dengan menggunakan media video pembelajaran. Instrumen berupa kuesioner yang digunakan untuk mengetahui validitas produk yang sudah dikembangkan terlebih dahulu di uji validitas butir oleh dua orang dosen yang sudah berkompeten di bidangnya.

Tabel 5. Kompetensi Dasar dan Indikator

\section{KOMPETENSI DASAR}

3.3 Menjelaskan perbandingan dua besaran yang berbeda (kecepatan sebaai perbandingan jarak dengan waktu, debiit sebagai perbandingan volume dan waktu

\section{INDIKATOR}

3.3.1. Menentukan hubungan kecepatan jarak dan waktu yang benar

3.3.2. Mengitung kecepatan, jarak dan waktu 


\begin{tabular}{cc}
\hline KOMPETENSI DASAR & INDIKATOR \\
\hline $\begin{array}{c}\text { 4.3. Menyelesaikan masalah yang berkaitan } \\
\text { dengan perbandingan dua besaran yang } \\
\text { berbeda (kecepatan, debit) }\end{array}$ & $\begin{array}{c}\text { 4.3.1. Menyelesaikan soal yang berhubungan } \\
\text { dengan kecepatan, jarak dan waktu }\end{array}$ \\
\hline
\end{tabular}

\section{Pengembangan (Development)}

Pada tahap pengembangan, dilakukan pembuatan media berdasarkan rancangan yang telah di buat. Kegiatan yang pertama dilakukan adalah pengumpulan bahan atau materi untuk video pembelajaran. Adapun bahan tersebut didapatkan dari buku ajar matematika kelas $\mathrm{V}$ dan buku-buku lainnya yang relevan. Media video pembelajaran yang dibuat terdiri dari 5 scene, yaitu opening, pembuka, materi pembelajaran, kesimpulan, dan latihan soal. Adapun beberapa bagian-bagian media video pembelajaran yang telah dibuat ditunjukkan pada gambar 1. Pada tahap ini, produk yang telah selesai dibuat atau dikembangkan, dilakukan pengujian oleh ahli. Tahap ini bertujuan untuk mengetahui validitas dari produk yang dikembangkan. Pengujian pada produk ini dilakukan dengan menguji produk kepada para ahli yang berkopeten dalam bidangnya. Ahli-ahli tersebut meliputi 1 orang ahli media dan desain, 1 orang ahli materi, 1 orang praktisi atau guru, 3 orang siswa yang memiliki kompetensi rendah sedang, dan tinggi sebagai uji perseorangan, serta 6 orang siswa yang memiliki kompetensi rendah sedang, dan tinggi sebagai uji kelompok kecil. Analisis dilakukan dengan cara menghitung rata-rata skor yang diperoleh pada lembar validasi penilaian materi, penilaian media, penilaian perorangan dan kelompok kecil oleh ketiga ahli dan sembilan orang peserta didik. Nilai tersebut selanjutnya dikonversi dengan pedoman konversi skala lima untuk mengetahui tingkat validitas media video pembelajaran yang dikembangkan. Pada hasil analisis data akan dipaparkan empat pokok bahasan yaitu, 1) hasil uji coba oleh ahli media pembelajaran, 2) hasil uji coba oleh ahli materi pembelajaran, 3) hasil uji perseorangan, dan 4) hasil uji kelompok kecil. Hasil lebih rinci dari uji coba poduk tersaji pada tabel 6. Analisis data menunjukkan bahwa pengembangan produk video pembelajaran memiliki rata-rata berada pada rentangan $4,01<X \leq 5,01$ berdasarkan pada tabel pedoman konversi skala lima. Dengan demikian dapat diindikasikan bawa produk video pembelajaran dapat dinyatakan valid. Selanjutnya produk yang telah diberi nilai oleh para ahli kemudian dilakukan revisi. Produk direvisi dengan menyesuaikan dari komentar atau masukan oleh ahli pada saat penilaian produk.

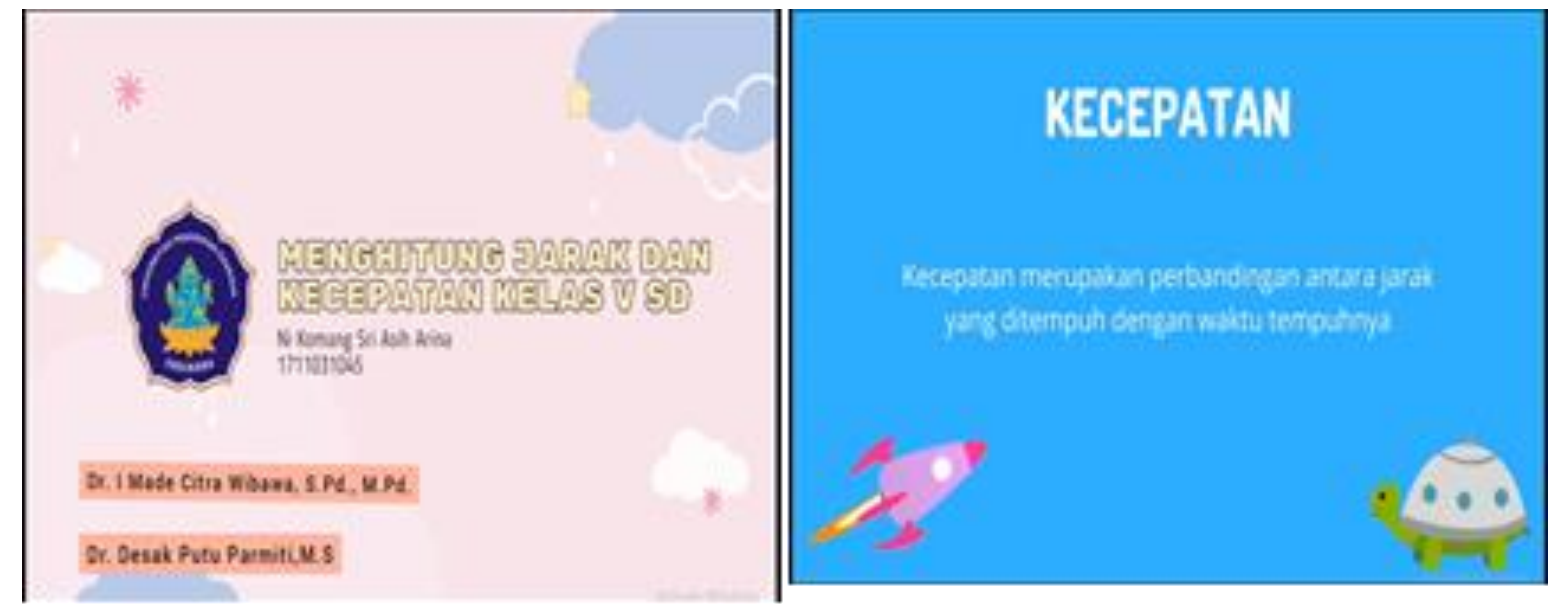

Gambar 1. Tampilan Video Pembelajaran

Tabel 6. Hasil Uji Coba Produk

\begin{tabular}{clc}
\hline No & \multicolumn{1}{c}{ Subjek Uji Coba } & Validasi \\
\hline 1 & Uji Ahli Media Pembelajaran & 4,72 \\
2 & Uji Ahli Materi Pembelajaran & 4,75 \\
3 & Uji Perseorangan & 4,77 \\
4 & Uji Keompok Kecil & 4,61 \\
\hline
\end{tabular}

\section{Pembahasan Hasil Penelitian}

Pada penelitian pengembangan ini menghasilkan produk sebuah video pembelajaran pada topik jarak dan kecepatan kelas V SD. Produk ini telah melalui tahap pengujian oleh ahli dan uji coba kepada siswa kelas V SD serta telah dilakukan revisi dengan menyesuaikan kepada komentar atau saran dari ahli yang menguji produk ini. Hasil analisis data dipaparkan dari proses pengembangan produk video pembelajaran ini serta hasil uji validasi dari pengembangan video pembelajaran. Dikembangkannya media video penbelajaran bertujuan untuk 
memfasilitasi peserta didik agar lebih mudah memahami materi yang dipelajari dalam proses pembelajaran. Selain itu, media ini membantu guru dalam menjelaskan materi. Hal tersebut sejalan dengan pengertian dari media video yaitu Berdasarkan teori perkembangan kognitif menurut piaget menyatakan bahwa anak sekolah dasar pada usia 6-12 tahun berada pada tahap operasional konkret. Pada tahap ini, anak sudah cukup matang untuk menggunakan pemikiran logika atau operasi, tetapi hanya untuk objek fisik belum dapat berfikir secara abstrak (Ibda, 2015), sehingga memerlukan bantuan berupa media pembelajaran pada proses pembelajaran untuk mengkonkritkan sesuatu yang abstrak. Pembuatan atau pemilihan media pembelajaran harus disesuaikan dengan karakteristik peserta didik yang beraneka ragam dan gaya belajar yang berbeda-beda seperti gaya belajar visual, auditorial, dan kinestetik (Ashari et al., 2020; Busyaeri et al., 2016). Penerapan media video pembelajaran dapat membantu peserta didik yang memiliki gaya belajar yang berbeda-beda karena media ini merupakan media gabungan dari teks, gambar, musik dan animasi-animasi.

Berdasarkan hasil validitas yang dilakukan oleh para ahli dari media video pembelajaran yang direview menyatakan media video layak untuk digunakan. Hal tersebut dikarenakan penyajian materi dengan video, teks, animasi-animasi dan gambar disajikan dengan baik sehingga menjadi lebih menarik dan dapat menumbuhkan motivasi belajar. Selain itu kualitas dan tampilan media video yang dikembangkan sudah sesuai dengan syaratsyarat media yang baik, yaitu efektif, efisien, dan komunikatif. Temuan penelitian ini sejalan dengan penelitian yang dilaksanakan oleh Tegeh et al., (2019). Hasil penelitian menyatakan pengembangan media video pembelajaran yaitu: pertama, hasil review ahli isi mata pelajaran menunjukkan produk berpredikat sangat baik. kedua, hasil review ahli media menunjukkan produk berpredikat sangat baik. ketiga, hasil review ahli desain pembelajaran menunjukkan produk berpredikat sangat baik, dan hasil uji perorangan menunjukkan produk berpredikat sangat baik, hasil uji kelompok kecil menunjukkan produk berpredikat sangat baik. Efektivitas pengembangan menunjukkan bahwa video pembelajaran yang dikembangkan efektif meningkatkan hasil belajar Agama Hindu. Selain itu, tujuan pembelajaran pada media video pembelajaran sudah sesuai dengan kompetensi dasar dan indikator. Selain itu, bahasa yang digunakan dalam media video pembelajaran sudah sesuai dengan karakteristik peserta didik. Temuan penelitian ini, sejalan dengan penelitian yang dilakukan oleh Bekagema et al., (2016); Melinda et al., (2018); Suryansyah \& Suwarjo (2016). Hasil penelitian menunjukkan bahwa media video pembelajaran layak digunakan menurut ahli materi dan ahli media dengan kategori "baik". Data hasil uji kelayakan produk media video pembelajaran diperoleh dari hasil validasi yang dilakukan oleh ahli media dan ahli materi.

Penelitian ini memiliki perbedaan dengan penelitian lainnya dimana perbedaan tersebut terletak pada KD dan indikator yang dikembangkan. Selain itu, belum ada yang mengembangkan media yang sejenis pada topik jarak dan kecepatan pada pembelajaran matematika di kelas v sekolah dasar. Disamping itu, media yang dikembangkan dilengkapi dengan materi, gambar, video pembelajaran, dan soal-soal sesusai dengan materi yang diajarakan. Media video dikembangkan berdasarkan hasil analisis kebutuhan di lapangan. Sehingga media ini dapat menjadi solusi dalam mengatasi permasalahan yang ada. Penggunaan media video sangat cocok digunakan dalam proses pembelajaran jarak jauh atau pembelajaran secara daring maupun luring. Hal ini dikatakan sesuai karena dalam penggunaan media siswa dapat membaca materi yang dilengkapi dengan gambar-gambar dan didukung dengan adanya video pembelajaran, sehingga siswa akan lebih paham akan materi yang dipelajari (Ana, 2018; Hidayati et al., 2019). Dengan demikian pengembangan video pembelajaran dengan media topik jarak dan kecepatan ini diharapkan mampu menambah wawasan dan pengetahuan siswa serta memberikan pemahaman yang lebih mendalam mengenai materi tersebut. Penggunaan video pembelajaran ini juga cocok digunakan untuk meningkatkan hasil belajar siswa. Pernyataan tersebut didukung pernyataan hasil penelitian yaitu penggunaan metode demonstrasi melalui media gambar pada audio visual/video dapat meningkatkan hasil belajar siswa. Hal ini menunjukkan video pembelajaran yang dikembangkan layak digunakan untuk mendukung proses pelaksanaan pembelajaran (Arsyad \& Sulfemi, 2018; Khasanudin et al., 2020). Oleh sebab itu, video pembelajaran pada topik jarak dan kecepatan di kelas $\mathrm{V}$ sekolah dasar merupakan media video pembelajaran yang dapat memberikan pengaruh bagi siswa terutama pada hasil belajar siswa yang semakin meningkat. Adapun implikasi dari penelitian pengembangan ini sebagai berikut. Bagi siswa, dapat dipergunakan dalam membantu untuk memudahkan dalam memahami materi terutama pada topik jarak dan kecepatan pada pembelajaran matematika. Karena media video pembelajaran dapat diakses melalui handpone, laptop, ataupun komputer sehingga dapat digunakan di rumah ataupun di sekolah. Bagi guru, diharapkan dengan adanya pengembangan media video pembelajaran ini dapat membantu dalam menjelaskan materi kepada siswa serta memecahkan permasalahan yang dialami oleh guru dalam melaksanakan pembelajaran daring. Bagi sekolah, dengan adanya penelitian ini diharpkan menjadikan salah satu opsi dalam membatu pelaksanaan proses pembelajaran di sekolah. Bagi peneliti lain, diharpkan dengan adanya penelitian ini dapat dipergunakan sebagai referensi dalam melakukan penelitian yang relevan. 


\section{SIMPULAN}

Media video pembelajaran topik jarak dan kecepatan pada mata pelajaran matematika siswa kelas V SD termasuk pada kualifikasi sangat baik dan dinyatakan valid. Dengan demikian saran yang dapat diajukan berdasarkan hasil penelitian ini, yaitu media video pembelajaran ini layak untuk dikembangkan sehingga dapat memberikan kontribusi yang positif terhadap peningkatan proses dan hasil belajar matematika siswa.

\section{DAFTAR PUSTAKA}

Ana, R. F. R. (2018). Penggunaan Model Four D dalam Pengembangan Bahan Ajar Mata Kuliah Perencanaan Pembelajaran pada Mahasiswa STKIP PGRI Tulungagung. Jurnal Pedagogy, 5(2). https://ejournal.upm.ac.id/index.php/pedagogy/article/view/14.

Anugrahana, A. (2020). Hambatan, Solusi dan Harapan : Pembelajaran Daring Selama Masa Pandemi Covid-19 Oleh Guru Sekolah Dasar. Scholaria: Jurnal Pendidikan Dan Kebudayaan, 10(3), 282-289. https://ejournal.uksw.edu/scholaria/article/view/4033.

Arsyad, A., \& Sulfemi, W. B. (2018). Metode Role Playing Berbantu Media Audio Visual Pendidikan dalam Meningkatkan Belajar IPS. Jurnal PIPSI (Jurnal Pendidikan IPS Indonesia), 3(2), 41-46. http://dx.doi.org/10.26737/jpipsi.v3i2.1012.

Ashari, J., Asfar, A. H., Kurnia, A., FA, A. N., Fatmawati, F., \& Nurwahyuni, N. (2020). Sinergitas Media Gurecceng Melalui Model Pembelajaran Controlling (Contextual Problem Solving) Terhadap Kemampuan Berpikir Realistik Siswa. In Seminar Nasional Hasil Penelitian \& Pengabdian Kepada Masyarakat (SNP2M), 170174. http://jurnal.poliupg.ac.id/index.php/snp2m/article/download/2348/2060.

Atmoko, S. W., Cahyadi, F., \& Listyarini, I. (2017). Pengembangan Media Utama (Ular Tangga Matematika) dalam Pemecahan Masalah MatematikaMateri Luas Keliling Bangun Datar Kelas III SD/MI. Al Ibtida: Jurnal Pendidikan Guru MI, 4(1), 119-128. http://dx.doi.org/10.24235/al.ibtida.snj.v4i1.1476.

Aziz, L. A. (2018). Pengembangan Media Pembelajaran Permainan Ular Tangga Materi Operasi Hitung Pecahan Kelas V SDN 24 Cakranegara. Media Pendidikan Matematika, 6(2), 96-103. https://doi.org/https://doi.org/10.33394/mpm.v6i2.1689.

Bekagema, M. D., Mahadewi, L. P. P., \& Tastra, I. D. K. (2016). Pengembangan Video Pembelajaran Budaya Masyarakat Hindu Bali Kelas IV SDN 3 Banjar Tegal. Jurnal Edutech Undiksha, 4(3). http://dx.doi.org/10.23887/jeu.v4i3.8561.

Busyaeri, A., Udin, T., \& Zaenudin, A. (2016). Pengaruh Penggunaan Video Pembelajaran Terhadap Peningkatan Hasil Belajar Mapel Ipa Di Min Kroya Cirebon. Al Ibtida: Jurnal Pendidikan Guru MI, 3(1), 116-137. https://doi.org/10.24235/al.ibtida.snj.v3i1.584.

Chauhan, S. (2017). A meta-analysis of the impact of technology on learning effectiveness of elementary students. Computers \& Education, 105, 14-30. https://doi.org/10.1016/j.compedu.2016.11.005.

Fitriyani, Y., Fauzi, I., \& Sari, M. Z. (2020). Motivasi Belajar Mahasiswa Pada Pembelajaran Daring Selama Pandemik Covid-19. Jurnal Hasil Penelitian Dan Kajian Kepustakaan Di Bidang Pendidikan, Pengajaran Dan Pembelajaran, 6(2), 165-175. https://doi.org/10.33394/jk.v6i2.2654.

Hariati, P. N. S., Lily, R., \& Islamiani, S. (2020). Pengaruh Penggunaan Media Video Animasi Terhadap Respon Siswa Dalam Pembelajaran Matematika Pada Materi Operasi Bilangan Bulat. Jurnal Pembelajaran Dan Matematika Sigma, 6(1), 18 - 22. https://doi.org/10.36987/jpms.v6i1.1657.

Hidayah, I., \& Sugiarto. (2015). Model of Independent Working Group of Teacher and Its Effectiveness towards the Elementary School Teacher's Ability in Conducting Mathematics Learning. Procedia-Social and Behavioral Sciences, 214, 43-50. https://doi.org/10.1016/j.sbspro.2015.11.591.

Hidayati, A. S., Adi, E. P., \& Praherdhiono, H. (2019). Pengembangan Media Video Pembelajaran untuk Meningkatkan Pemahaman Materi Gaya Kelas IV di SD Sukoiber 1 Jombang. JINOTEP Uurnal Inovasi Teknologi Pembelajaran), 6(1), 45-50. http://journal2.um.ac.id/index.php/jinotep/article/view/7401.

Hong, J.-C., Lee, Y.-F., \& Ye, J.-H. (2021). Procrastination predicts online self-regulated learning and online learning ineffectiveness during the coronavirus lockdown. Personality and Individual Differences, 1-8. https://doi.org/10.1016/j.paid.2021.110673.

Hwang, G. J., Wang, S. Y., \& Lai, C. L. (2020). Effects of a social regulation-based online learning framework on students' learning achievements and behaviors in mathematics. Computers and Education, 160, 104031. https://doi.org/10.1016/j.compedu.2020.104031.

Ibda, F. (2015). Perkembangan Kognitif : Teori Jean Piaget. Intelektualita, 3(1), 27-38.

Ilhami, R. S., \& R, D. (2017). Penilaian Kinerja Karyawan dengan Metode AHP dan Rating Scale. Jurnal Optimasi Sistem Industri, 16(2). https://doi.org/10.25077/josi.v16.n2.p150-157.2017.

Janah, F. N. M., Sulasmono, B. S., Widyanti, E., \& Setyaningtyas. (2019). Peningkatan Hasil Belajar Matematika Melalui Model Pembelajaran Problem Based Learning Berbantuan Media Video Siswa Kelas IV Sekolah Dasar. Jurnal Pendidikan Dasar, 7(1), 63-73. /https://doi.org/10.20961/jpd.v7i1.29002.

Jr., L. D. L., Tiangcoa, C. E., Sumalinog, D. A. G., Sabarillo, N. S., \& Mark, J. (2021). An effective blended online 
teaching and learning strategy during the Covid-19 pandemic. Education for Chemical Engineers, 35, 116-131./https://doi.org/10.1016/j.ece.2021.01.012.

Kenedi, A. K., Hendri, S., Ladiva, H. B., \& Nelliarti. (2018). Kemampuan Koneksi Matematis Siswa Sekolah Dasar Dalam Memecahkan Masalah Matematika. Jurnal Numeracy, 5(2), 226-235. https://doi.org/10.46244/numeracy.v5i2.396.

Khasanudin, M., Cholid, N., \& Putri, L. I. (2020). Pengembangan Media Audio Visual Berbasis Animation Dalam Pembelajaran Matematika Materi Bangun Ruang Untuk Kelas V Sd/MI. Journal of Elementary Education, 3(5). https://journal.ikipsiliwangi.ac.id/index.php/collase/article/view/5888.

Masrifatun, M. A. (2020). Peningkatan Hasil Belajar Matematika tentang Nilai dan Kesetraan Pecahan Mata Uang Melalui Media Video Pembelajaran Pada Siswa Sekolah Dasar. In Social, Humanities, and Educational Studies (SHEs): Conference Series, 3(3), 118-124. /https://doi.org/10.20961/shes.v3i3.45814.

Melinda, V. A., Degeng, N. S., \& Kuswandi, D. (2018). Pengembangan Media Video Pembelajaran IPS Berbasis Virtual Field Trip (VFT) Pada Kelas V SDNU Kratonkencong. JINOTEP Jurnal Inovasi Dan Teknologi Pembelajaran): Kajian Dan Riset Dalam Teknologi Pembelajaran. https://doi.org/10.17977/UM031V3I22017P158.

Mishra, D. L., Gupta, D. T., \& Shree, D. A. (2020). Online Teaching-Learning in Higher Education during Lockdown Period of COVID-19 Pandemic. International Journal of Educational Research Open, 100012. https://doi.org/10.1016/j.ijedro.2020.100012.

Mishra, L., Gupta, T., \& Shree, A. (2020). Online teaching-learning in higher education during lockdown period of COVID-19 pandemic. International Journal of Educational Research Open, June, 100012. https://doi.org/10.1016/j.ijedro.2020.100012.

Oktafia, I. H., \& Wulandari, S. S. (2020). Pembelajaran Daring Sebagai Upaya Study From Home (SFH) Selama Pandemi Covid 19. Jurnal Pendidikan Administrasi Perkantoran, 8(3). https://doi.org/10.1093/fampra/cmy005.

Oktawirawan, D. H. (2020). Faktor Pemicu Kecemasan Siswa dalam Melakukan Pembelajaran Daring di Masa Pandemi Covid-19. Jurnal Ilmiah Universitas Batanghari Jambi, 20(2), 541-544. https://doi.org/10.33087/jiubj.v20i2.932.

Perdana, S. A., \& Slameto. (2016). Penggunaan Metode Problem Based Learning (PBL) Berbantuan Media Audio Visual Untuk Meningkatkan Hasil Belajar Matematika Siswa Sekolah Dasar. Jurnal Pendidikan Dasar $\begin{array}{llll}\text { Universitas } & \text { Sebelas } & \text { Maret, } & \text { 73-78. }\end{array}$ https://jurnal.fkip.uns.ac.id/index.php/diksar/article/view/9300.

Prihanto, D. A., \& Yunianta, T. N. H. (2018). Pengembangan Media Komik Matematikapada Materi Pecahan Untuk Siswa Kelas V Sekolah Dasar. Jurnal Ilmiah Pendidikan Matematika, 5(1), 79-90. https://ejournal.stkipbbm.ac.id/index.php/mtk/article/view/137.

Rachmawati, I., Supriyono, S., \& Pangestika, R. R. (2021). Pengembangan Media Buletin Matematika Berbasis Pendekatan Realistik Pada Siswa Sekolah Dasar. Jurnal Pendidikan Dan Pembelajaran Matematika, 3(1), 32-44. https://doi.org/10.35316/alifmatika.2021.v3i1.32-44.

Rigianti, H. A. (2020). Kendala Pembelajaran Daring Guru Sekolah Dasar Di Kabupaten Banjarnegara. Elementary School, 7, 297-302. https://journal.upy.ac.id/index.php/es/article/view/768.

Scherer, R., Howard, S. K., Tondeur, J., \& Siddiq, F. (2021). Profiling teachers' readiness for online teaching and learning in higher education: Who's ready? Computers in Human Behavior, 118, 1-16. https://doi.org/https://doi.org/10.1016/j.chb.2020.106675.

Suryansyah, T., \& Suwarjo. (2016). Pengembangan Video Pembelajaran Untuk Meningkatkan Motivasi Dan Hasil Belajar Kognitif Siswa Kelas IV SD. Jurnal Prima Edukasia, 4(2), 209-221. https://doi.org/10.21831/jpe.v4i2.8393.

Tegeh, I. M., S., A. H., \& Dwipayana, K. (2019). Pengembangan Media Video Pembelajaran dengan Model Pengembangan 4D pada Mata Pelajaran Agama Hindu. Jurnal Mimbar Ilmu, 24(2). /http://dx.doi.org/10.23887/mi.v24i2.21262.

Tuma, F. (2021). The use of educational technology for interactive teaching in lectures. Annals of Medicine and Surgery 62, 231-235. /https://doi.org/10.1016/j.amsu.2021.01.051.

Unaenah, E., \& Sumantri, M. S. (2019). Analisis Pemahaman Konsep Matematis Siswa Kelas 5 Sekolah Dasar Pada Materi Pecahan. Jurnal Basicedu, 3(1), 106-111.

Widodo, S., \& Kartikasari. (2017). Pembelajaran Pemecahan Masalah Matematis Siswa Sekolah Dasar Dengan Model Creative Problem Solving (CPS). Prisma, 6(1), 57-65. https://doi.org/https://doi.org/10.35194/jp.v6i1.28. 